\title{
Robert Hooke as Geologist and Evolutionist
}

\author{
By W. N. Edwards, Geological Department, British Museum (Natural History)
}

\begin{abstract}
A LTHOUGH a very large volume would be required to do full justice to every aspect of Robert Hooke's genius, it is somewhat surprising that so little reference has been made in this tercentenary of his birth to his evolutionary views. Indeed, apart from an article by A. P. Pavlow entitled "Robert Hooke, un évolutioniste oublié du XVII ${ }^{\mathrm{e}}$ siècle" (Palaeobiologica, $1 ;$ 1928), and brief references, with extracts from his writings, in a "Guide to the Early History of Palæontology" published by the British Museum (1931), Hooke's belief in the mutability of species has been largely overlooked.
\end{abstract}

Just a century ago, Darwin, observing the varieties of certain creatures peculiar to each island of the Galapagos, noted that "such facts would undermine the stability of species": more than a century and a half earlier (in 1668) Hooke wrote that "there have been many other species of creatures in former ages, of which we can find none at present; and 'tis not unlikely also but that there may be divers new kinds now, which have not been from the beginning" ("A Discourse of Earthquakes", Posthumous Works, 1705, p. 291); and again, that there have been "divers species wholly destroyed and annihilated, and divers others changed and varied" (ibid., p. 327). The same idea is expressed in similar terms in other passages, and one can only wish that Hooke had pursued it further, instead of wandering off into discussions of Chinese printing, the structure of the Pyramids, and whether the Romans used sheet lead for protecting their ships.

Hooke based his argument on the fossils which he had observed and collected in southern England: many of these were extinct, and others suggested different, even tropical conditions; the very existence of marine fossils inland implied movements of the crust, and these uplifts of the land and transgressions of the sea would alter the conditions of life and react on the animals and plants. "Alteration of the climate, soil, and nourishment" may "cause a very great change in the shape and other accidents of an animated body" (p. 327), and it is interesting to note that Hooke appeals to the variation of domesticated animals in support of his position.

That Hooke recognised the possibility of identifying strata by their fossils and "raising a chronology out of them" more than a hundred years before William Smith applied the principle is well known ; that he was the first, for example, to describe the structure of ammonites, to discover a fossil foraminifer, and to apply the microscope to the study of fossil wood has also been noted. His account of different types of fossilisationmoulds, casts and petrifactions-is admirable. His speculations on the possibility of shifting poles, and whether England once lay "within the torrid zone" are of interest, but his insistence on the importance of "earthquakes" has sometimes led, perhaps rather unfairly, to his being dismissed as a 'catastrophist'; his term "earthquake" clearly covered long continued crustal movements. "Many places by degrees are made submarine," he wrote, and "many submarine regions must become dry land, and many other lands will be overflown, and these variations being slow and by degrees will leave very lasting remarks ..." (written about 1686; Posthumous Works, p. 347). The agencies at work on the face of the earth, though they "may have been much greater and more powerful" in the past, were "still of the same kind" (1694, p. 449).

Nor, in his advocacy of earth-movements, did Hooke overlook the weathering, denuding and levelling action of streams and rivers, tides and currents, rain and wind (1668; pp. 312-316). "Many changes," he wrote in 1694, "may have happened to the earth, of which we can have no written history or accounts. And to me it seems very absurd to conclude, that from the beginning things have continued in the same state that we now find them, since we find everything to change and vary in our own remembrance" (p. 450). Finally, in the latest "discourse of the causes of earthquakes", dated 1699, he wrote that the earth "is in a state of progression from one degree of perfection to that of another degree, which may be termed of perfection for as much as it is the progress and operation of nature; and at the same time it may be conceived in a progress to corruption and dissolution in as much as it is continually changed from its preceding state".

Hooke was, in brief, far in advance of any other geologist of the seventeenth century, not excepting the acute Dane, Steno, and it may eren be 
remarked that the standard of his drawings (for example, of ammonites) is not always equalled at the present day. Some of his work was quoted by eighteenth century geological writers, and doubtless helped to prepare the ground for the great advances at the close of that century. But we do not even know whether William Smith had read the "Discourses of Earthquakes", and there is no sign that Hooke's evolutionary views were appreciated.

\title{
Cosmic Rays and the Origin of Species*
}

\author{
By Dr. H. Hamshaw Thomas, M.B.E., F.R.S.
}

$\mathrm{W}^{\mathrm{H}}$ HEN we turn to consider wild plants in Nature, two lines of inquiry present themselves: (1) the comparison of the number of plant species in warm mountain and lowland regions, and (2) the question of endemic species.

It would be interesting to compare the floras of regions where, owing to altitude and latitude, the cosmic ray fall is great, but the conditions are favourable for plant growth, with regions having similar climatic conditions at low altitudes; but the data now available scarcely allow this to be done. There can be, however, no doubt that the floras of mountain regions in the tropics and warm temperate zones are much richer in species than the lowland areas. Thus according to Standley ${ }^{20}$, the known flora of the tiny republic of Costa Rica contains more than 6,000 species of vascular plants, approximately the same number as in the whole of the south-eastern United States, although its area is less than half of the area of Florida and it contains mountain ranges not yet explored by botanists. Its mountains rise to more than $11,000 \mathrm{ft}$., and more than half its area lies above $3,000 \mathrm{ft}$. Its flora is especially rich in orchids, nearly 1,000 species having been recorded; they appear to reach their best development at about $6,000 \mathrm{ft}$. When Hemsley described the flora of Mexico and Central America, he stated that the species of angiosperms in this region outnumbered those in the whole of North America by some 2,200. No doubt the habitats in these tropical mountain regions are very varied, but it may be questioned as to whether the immense richness of species can be explained in this way. Costa Rica is an interesting case because it is a fairly recent mountain area, and was most probably submerged in late Eocene and Oligocene times ${ }^{21}$, while the very high percentage of endemics suggests that its flora cannot be regarded as merely due to the spread of species from the north and south.

It would be interesting to know more about the relative numbers of forms at different altitudes in

\footnotetext{
* Continued from $p .53$
}

widespread genera. The genus Primula might be quoted in support of my ideas, for while the Vernales section is very widespread in Europe and northern. Asia, mainly at low altitudes, it contains only about nineteen species; but many of the other sections which live on high mountains are very much richer in species and endemic forms; for example, the Petiolares with sixty-six species, the Nivales with sixty-one ${ }^{22}$. In all, there seems to be about 330 species of mountain primulas. Almost all the other alpine genera of the Primulacex are much richer in species than the genera of the plains.

The discussion of endemic species and genera raises many difficulties which cannot be solved at present. There can be no doubt that many endemics are survivors of races which were once widespread, for example, Matonia, Cupressus macrocarpa ${ }^{23}$ and Neviusia. On the other hand, it seems fairly certain that plants like the tetraploid subspecies and varieties of Biscutella loevigata $^{24}$, and several of the European alpine species of Soldanella and Primula are of comparatively recent origin. Probably as time goes on and endemic species receive more exact attention, we shall be in a position to distinguish new forms from relics. Cockayne in his survey of the flora of New Zealand divides up the numerous endemic plants of the region into groups according to their affinities, and concludes that the endemics closely related to other New Zealand species, and which may be considered of comparatively recent origin, make up 43 per cent of the whole flora and 58 per cent of the total number of its endemics ${ }^{25}$. The alpine flora of New Zealand numbers 945 species as against 998 species in the lowlands; 597 species belong to the high mountains, and of these no less than 94 per cent are endemic ${ }^{25}$. Many of the lowland plants are also endemic, but Cockayne considers that this group consists largely of descendants of an ancient palæotropic stock, often not perfectly attuned to the present-day climate. 